\title{
PENGGUNAAN MODEL PEMBELAJARAN DISCOVERY LEARNING DALAM MENINGKATKAN HASIL BELAJAR PAI PADA PESERTA DIDIK KELAS XI IPA.5 SMA NEGERI 1 OGAN KOMERING ULU
}

\author{
St. Karamah \\ Guru SMA Negeri 1 Ogan Komering Ulu \\ karamah@gmail.com
}

\begin{abstract}
ABSTRAK
Penelitian ini bertujuan untuk mengetahui penggunaan model pembelajaran discovery learning dapat meningkatkan hasil belajar PAI pada Peserta didik Kelas XI IPA.5 SMA Negeri 1 Ogan Komering Ulu. Penelitian yang digunakan adalah Penelitian Tindakan Kelas (PTK) atau Classroom Action Research (CAR) yang bertujuan untuk memperbaiki dan mencari solusi dari persoalan yang nyata dan praktis dalam meningkatkan proses pembelajaran di dalam kelas. Dalam penelitian ini terdapat beberapa siklus. Setiap siklus terdiri atas 4 tahap kegiatan yang saling terkait dan berkesinambungan yaitu: perencanaan tindakan (planning), pelaksanaan tindakan (acting), pengamatan (observing) dan refleksi (reflecting). Penelitian ini dilaksanakan di SMA Negeri 1 Ogan Komering Ulu. Adapun waktu penelitian ini dilaksanakan pada bulan Agustus sampai dengan bulan Oktober 2019 tahun pelajaran 2019/2020. Indikator keberhasilan dalam penelitian ini adalah meningkatnya pemahaman belajar peserta didik yang ditunjukkan dengan meningkatnya hasil belajar peserta didik dibandingkan dengan tahun sebelumnya yaitu minimal peserta didik memperoleh nilai 70 . Sedangkan untuk keberhasilan klasikal jika $85 \%$ dari seluruh peserta didik memperoleh nilai $\geq$ 70. Data yang diperoleh berupa hasil tes formatif, lembar observasi kegiatan belajar mengajar. Dari hasil analis didapatkan bahwa ketuntasan belajar meningkat dari sebelum tindakan dan sesudah tindakan, yaitu; pra siklus (31.43\%), siklus I (68.57\%), dan siklus II (91.43\%). Kesimpulan dari penelitian ini adalah model pembelajaran discovery learning dapat meningkatakan hasil belajar peserta didik XI IPA.5 SMA Negeri 1 Ogan Komering Ulu serta model pembelajaran discovery learning ini dapat digunakan sebagai salah satu alternatif pembelajaran PAI.
\end{abstract}

Kata Kunci: Hasil Belajar,PAI, model pembelajaran discovery learning

\begin{abstract}
This study aims to determine the use of discovery learning learning models can improve learning outcomes of PAI in Class XI IPA.5 students of SMA Negeri 1 Ogan Komering Ulu. The research used is Classroom Action Research (CAR) or Classroom Action Research (CAR) which aims to improve and find solutions to real and practical problems in improving the learning process in the classroom. In this study there are several cycles. Each cycle consists of 4 stages of activities that are interrelated and continuous, namely: action planning, acting, observing and reflecting. This research was conducted at SMA Negeri 1 Ogan Komering Ulu. The time of this research was carried out in August to October 2019 2019/2020 academic year. The indicator of success in this study is an increase in students' understanding of learning as indicated by the increase in student learning outcomes compared to the previous year, namely students get a minimum score of 70 . While for classical success if $85 \%$ of all students get a value of $\geq 70$. Data obtained in the form of formative test results, observation sheets of teaching and learning activities. From the results of the analyst found that mastery learning increases from before the
\end{abstract}


action and after the action, namely; pre cycle (31.43\%), cycle I (68.57\%), and cycle II (91.43\%). The conclusion of this study is the discovery learning model can improve student learning outcomes XI IPA.5 SMA Negeri 1 Ogan Komering Ulu and this discovery learning model can be used as an alternative to PAI learning.

Keywords: Learning Outcomes, PAI, discovery learning learning model

\section{PENDAHULUAN}

Pendidikan Agama Islam adalah usaha yang dilakukan secara sistematis dalam membimbing anak yang beragama Islam, sehingga ajaran Islam benar-benar diketahui, dimiliki, dan diamalkan oleh peserta didik baik tercermin dalam sikap, tingkah laku maupun cara berfikirnya. Melalui pendidikan Islam terjadilah proses pengembangan aspek kepribadian anak, yaitu aspek kognitif, aspek afektif dan aspek psikomotorik. Sehingga ajaran Islam diharapkan akan menjadi bagian integral dari pribadi anak yang bersangkutan. Dalam arti segala aktifitas anak akan mencerminkan sikap Islamiyah. Kurikulum adalah seperangkat rencana dan pengaturan mengenai tujuan, isi dan bahan pelajaran serta cara yang digunakan sebagai pedoman penyelenggaraan kegiatan pembelajaran untuk mencapai tujuan pendidikan tertentu. Tujuan tertentu ini meliputi tujuan pendidikan nasional serta kesesuaian dengan kekhasan, kondisi dan potensi daerah, satuan pendidikan dan peserta didik. Oleh sebab itu kurikulum disusun oleh satuan pendidikan untuk memungkinkan penyesuaian program pendidikan dengan kebutuhan dan potensi yang ada di daerah. Pendidikan dilakukan oleh seorang pendidik (guru), sebab guru adalah salah satu element yang penting dalam pendidikan yang secara langsung berhubungan dengan seseorang (anak didik) oleh karena itu pendidik (guru) harus berperan aktif dan mampu menempatkan kedudukannya sebagai tenaga professional yang dituntut untuk melakukan transformasi pengetahuan agar tercapai perkembangan anak didik secara maksimal yang positif.

Seorang pendidik maupun calon pendidik harus memiliki pengetahuan tentang metode-metode pengajaran serta mampu meningkatkan hasil belajar siswa agar siswa lebih giat lagi dalam belajar. Karakteristik guru yang baik selalu mengadakan perbaikan dan pengajaran serta mampu memberi variasi stimulus yaitu suatu kegiatan guru dalam konteks proses interaksi belajar mengajar yang ditujukan untuk meningkatkan hasil belajar siswa. Sehingga sebelum mengajar seorang guru harus dapat memilih metode 
yang tepat agar dalam kegiatan proses pembelajaran murid tidak merasa bosan, senantiasa berpartisipasi dan tercipta interaksi edukatif yang mempunyai pengertian hubungan timbal balik antara pendidik (guru) dan peserta didik (murid) dalam suatu sistem pengajaran

Permasalahan yang ditemui peneliti adalah rendahnya hasil belajar peserta didik pada pembelajaran Pendidikan Agama Islam. Hal ini didapat dari hasil nilai ulangan harian peserta didik yang masih banyak belum mencapai kriteria ketuntasan minimum (KKM). Data daftar nilai ulangan harian yang diperoleh peserta didik pada mata pelajaran Pendidikan Agama Islam menunjukkan $31,43 \%$ peserta didik mendapatkan nilai $\geq 70$ sedangkan sisanya $68.57 \%$ peserta didik mendapatkan nilai < 70. Itu artinya hampir setengah dari jumlah peserta didik belum mencapai KKM. Sedangkan untuk mencapai standart KKM peserta didik harus mendapatkan nilai $\geq 70$. Secara klasikal peserta didik peserta didik dikatakan tuntas belajar apabila $85 \%$ dari jumlah peserta didik memperoleh nilai $\geq 70$, sebaliknya peserta didik dikatakan belum tuntas belajar apabila memperoleh nilai < 70. Untuk mengatasi masalah tersebut, penulis mencoba mengaplikasikan model pembelajaran yang telah ada yaitu dengan menerapkan Model pembelajaran Discovery Learning.

Berdasarkan hasil yang dicapai perlu adanya suatu usaha untuk meningkatkan hasil belajar Pendidikan Agama Islam dengan menggunakan Model pembelajaran Discovery Learning. Penggunaan metode pembelajaran Discovery Learning saat belajar diharapkan dapat meningkatkan kegiatan belajar dan memperbaiki hasil belajar selanjutnya. Dengan menerapkan metode ini, pembelajaran tidak hanya terpusat pada guru tetapi peserta didik bisa lebih aktif dalam pembelajaran.

Berdasarkan pada permasalahan tersebut akan dilaksanakan penelitian pembelajaran PAI menggunakan model pembelajaran Discovery Learning . Discovery Learning merupakan istilah dalam bahasa inggris, ini merupakan Metode penemuan (discovery) diartikan sebagai prosedur mengajar yang mementingkan pengajaran, perseorangan, manipulasi obyek dan percobaan, sebelum sampai kepada generalisasi. Sehingga metode penemuan (discovery) merupakan komponen dari praktik pendidikan yang meliputi metode mengajar yang 
memajukan cara belajar aktif, berorientasi pada proses, mengarahkan sendiri, mencari sendiri, dan reflektif .

Berdasarkan paparan tersebut diatas maka peneliti ingin mencoba melakukan penelitian dengan judul "Penggunaan model pembelajaran Discovery Learning Dalam Meningkatkan Hasil Belajar Pendidikan Agama Islam Pada Peserta didik Kelas XI IPA.5 SMA Negeri 1 Ogan Komering Ulu”.

Berdasarkan latar belakang yang diuraikan diatas, maka rumusan masalah dalam penelitian ini adalah "apakah penggunaan model pembelajaran Discovery Learning dapat meningkatkan hasil belajar Pendidikan Agama Islam pada Peserta didik kelas XI IPA.5 SMA Negeri 1 Ogan Komering Ulu?”.

Adapun tujuan dari penelitian ini adalah untuk mengetahui penggunaan model pembelajaran Discovery Learning dapat meningkatkan hasil belajar Pendidikan Agama Islam pada Peserta didik kelas XI IPA.5 SMA Negeri 1 Ogan Komering Ulu.

"Belajar merupakan komponen paling vital dalam setiap usaha penyelenggaraan jenis dan jenjang pendidikan, sehingga tanpa proses belajar sesungguhnya tidak pernah ada pendidikan” (Sagala, 2010:13). Menurut Hamalik (2009:28), belajar adalah suatu proses perubahan tingkah laku melalui interaksi antara individu dan lingkungan. Proses dalam hal ini, merupakan urutan kegiatan yang berkesinambungan, bertahap, bergilir, dan terpadu yang secara keseluruhan mewarnai dan memberikan karakteristik terhadap belajar itu.

Belajar merupakan tindakan dan perilaku yang kompleks, sebagai tindakan belajar yang dialami oleh peserta didik sendiri. Dimyati dan Mujiono (dalam Sagala, 2010:13) mengemukakan peserta didik adalah penentu terjadinya atau tidak terjadinya proses belajar. Menurut Gagne (dalam Sagala, 2010:17) belajar adalah seperangkat proses kognitif yang mengubah sifat stimulasi lingkungan, melewati pengolahan informasi, menjadi kapabilitas baru. Belajar terjadi apabila ada hasil yang diperlihatkan, anak-anak maupun orang dewasa dapat mengingat kembali kata-kata yang pernah didengar atau dipelajari.

Pembelajaran kooperatif adalah suatu pengajaran yang melibatkan peserta didik untuk bekerja dalam kelompokkelompok untuk menetapkan tujuan bersama. (Felder, 1994: 2). Wahyuni (2001: 8) menyebutkan bahwa 
pembelajaran kooperatif merupakan strategi pembelajaran dengan cara menempatkan peserta didik dalam kelompok-kelompok kecil yang memiliki kemampuan berbeda. Sependapat dengan pernyataan tersebut Setyaningsih (2001: 8) mengemukakan bahwa metode pembelajaran kooperatif memusatkan aktivitas di kelas pada peserta didik dengan cara pengelompokan peserta didik untuk bekerjasama dalam proses pembelajaran.

Sebagai prosedur mengajar yang mementingkan pengajaran, perseorangan, manipulasi obyek dan percobaan, sebelum sampai kepada generalisasi. Sehingga metode penemuan (discovery) merupakan komponen dari praktik pendidikan yang meliputi metode mengajar yang memajukan cara belajar aktif, berorientasi pada proses, mengarahkan sendiri, mencari sendiri, dan reflektif (Suryosubroto 2009:178). Menurut Hanafiah metode penemuan (discovery) merupakan suatu rangkaian kegiatan pembelajaran yang melibatkan seluruh kemampuan siswa secara maksimal untuk mencari dan menyelidiki secara sistematis, kritis, dan logis sehingga siswa dapat menemukan sendiri pengetahuan, sikap, dan keterampilan sebagai wujud adanya perubahan tingkah laku .

Model discovery-inquiry atau Discovery Learning menurut Suryosubroto (2009) diartikan sebagai suatu prosedur mengajar yang mementingkan pengajaran perseorangan, manipulasi obyek dan lain-lain, sebelum sampai kepada generalisasi. Discovery adalah proses mental yang membuat siswa mengasimilasi sesuatu konsep atau sesuatu prinsip. Proses mental tersebut misalnya mengamati, menggolonggolongkan, membuat dugaan, menjelaskan, mengukur, membuat kesimpulan, dan sebagainya.

Penelitian ini dilaksanakan di SMA Negeri 1 Ogan Komering Ulu, dipilihnya sekolah ini sebagai tempat meneliti karena peneliti adalah sebagai guru PAI di kelas XI IPA.5 SMA Negeri 1 Ogan Komering Ulu.

Adapun waktu penelitian ini dilaksanakan pada bulan Agustus sampai dengan bulan Oktober 2019 tahun pelajaran 2019/2020, karena pada tahun pelajaran ini peneliti guru di kelas XI IPA.5 SMA Negeri 1 Ogan Komering Ulu, pokok bahasan yang disampaikan adalah " menganalisis makna Q.S. al- 
Maidah/5 : 48; Q.S. an-Nisa/4: 59, dan Q.S. at-Taubah/9 : 105".

Subjek yang dimaksud tindakan dalam penelitian ini adalah peserta didik kelas XI IPA.5 SMA Negeri 1 Ogan Komering Ulu yang berjumlah 35 peserta didik. Mereka merupakan peserta didik kelas XI IPA.5 semester I tahun pelajaran 2019/2020, sedangkan partisipan yang terlibat dalam penelitian ini adalah peneliti dan teman sejawat lainnya.

Prosedur dan langkah-langkah penelitian yang digunakan mengikuti model yang dikembangkan oleh Kemmis dan Robin MC Taggart (Kusumah, W. 2009 : 21) yang berupa model spiral. Perencanaan Kemmis mengunakan system spiral refleksi diri yang dimulai dengan rencana, tindakan, pengamatan, refleksi, perencanaan kembali merupakan suatu dasar untuk memecahkan masalah. Langkah-langkah operasional penelitian meliputi tahap persiapan, perencanaan (planning), tindakan (acting), pengamatan (observing), refleksi (reflecting).

\section{HASIL DAN PEMBAHASAN}

\section{Pra Penelitian}

Adapun rekapitulasi hasil tes pra siklus dapat dilihat pada tabel berikut:
Tabel 1 Hasil Tes Pra Siklus

\begin{tabular}{|c|c|c|}
\hline No. & Uraian & $\begin{array}{c}\text { Pra } \\
\text { Siklus } \\
\end{array}$ \\
\hline 1 & Nilai rata-rata tes & 62.57 \\
\hline 2 & $\begin{array}{l}\text { Jumlah siswa yang } \\
\text { tuntas belajar }\end{array}$ & 11 \\
\hline 3 & $\begin{array}{l}\text { Jumlah siswa yang } \\
\text { tidak tuntas belajar }\end{array}$ & 24 \\
\hline 4 & $\begin{array}{l}\text { Persentase ketuntasan } \\
\text { belajar }\end{array}$ & 31.43 \\
\hline 5 & $\begin{array}{l}\text { Persentase tidak } \\
\text { tuntas belajar }\end{array}$ & 68.57 \\
\hline
\end{tabular}

Berdasarkan data di atas dapat diketahui bahwa peserta didik yang nilainya mencapai kriteria ketuntasan minimal yang sudah ditetapkan yaitu 70 , sebagai berikut: peserta didik yang mendapatkan nilai di atas/sama dengan 70 hanya berjumlah 11 orang dengan persentase 31.43\%. Dan peserta didik yang mendapatkan nilai kurang dari 70 berjumlah 24 orang dengan persentase 68.57\%. Angka ini masih jauh dari indikator keberhasilan yang diharapkan yaitu $85 \%$ peserta didik yang memperoleh nilai diatas 70 .

\section{Pelaksanaan Siklus Pertama}

Siklus pertama dilaksanakan dalam dua kali pertemuan atau dua kali tatap muka. Siklus ini dilaksanakan pada hari Senin 5 Agustus 2019, dan Senin 12 Agustus 2019 jam ke 1 dan 2 di kelas XI 
IPA.5 SMA Negeri 1 Ogan Komering Ulu.

Setelah mengadakan ulangan harian siklus pertama dapat dilihat pada tabel sebagai berikut :

Tabel 2 Hasil Tes Pada Siklus I

\begin{tabular}{|c|c|c|}
\hline No. & Uraian & Siklus I \\
\hline 1 & Nilai rata-rata tes & 70 \\
\hline 2 & $\begin{array}{l}\text { Jumlah siswa yang tuntas } \\
\text { belajar }\end{array}$ & 24 \\
\hline 3 & $\begin{array}{l}\text { Jumlah siswa yang tidak } \\
\text { tuntas belajar }\end{array}$ & 11 \\
\hline 4 & $\begin{array}{ll}\begin{array}{l}\text { Persentase } \\
\text { belajar }\end{array} & \text { ketuntasan } \\
\end{array}$ & 68.57 \\
\hline 5 & $\begin{array}{l}\text { Persentase tidak tuntas } \\
\text { belajar }\end{array}$ & 31.43 \\
\hline
\end{tabular}

Sedangkan untuk hasil tes pada siklus I dapat dilihat pada tabel berikut:

Tabel 3 Hasil Tes

\begin{tabular}{cc}
\hline Uraian & $\begin{array}{c}\text { Siklus } \\
\text { I }\end{array}$ \\
\hline Rata-rata nilai tes pertemuan 1 & 68.57 \\
\hline
\end{tabular}

Rata-rata nilai tes pertemuan $2 \quad 71.43$

Rata-rata nilai 70

Dari tabel di atas dapat dijelaskan bahwa dengan menerapkan pembelajaran dengan menggunakan model pembelajaran Discovery Learning diperoleh nilai rata-rata hasil belajar peserta didik pada pertemuan pertama 68.57, dan pada pertemuan kedua 71.43 , sehingga nilai rata-rata peserta didik pada siklus I ini didapatkan 70. Untuk lebih jelas dapat dilihat pada grafik di bawah ini:

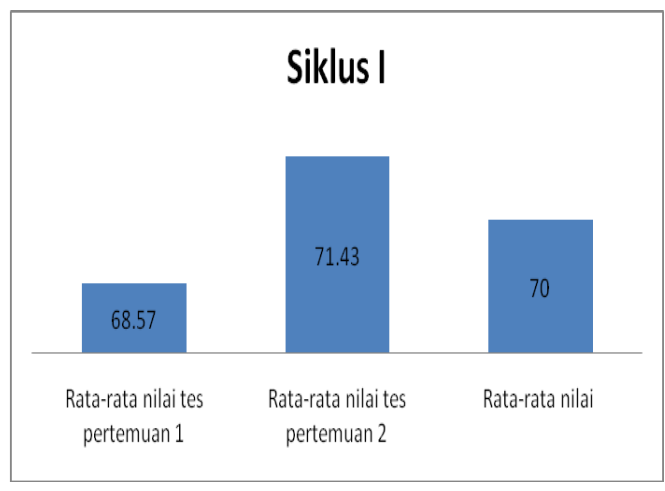

Grafik 1 Pada Siklus I

Berdasarkan tabel di atas dapat dijelaskan bahwa dengan menerapkan pembelajaran dengan menggunakan model pembelajaran Discovery Learning diperoleh ketuntasan belajar peserta didik pada pertemuan pertama peserta didik yang tuntas belajar hanya 21 orang dan yang tidak tuntas 14 orang. Sedangkan pada pertemuan kedua peserta didik yang tuntas belajar hanya 16, dan yang tidak tuntas 9 orang, jadi dapat disimpulkan rata-rata ketuntasan belajar peserta didik pada siklus I yang tuntas belajar 24 orang dan persentase $68.57 \%$, dan yang belum tuntas 11 arang dengan persentase 31.43 \%. Hasil tersebut menunjukkan bahwa pada siklus pertama secara klasikal peserta didik belum tuntas belajar, karena 
peserta didik yang memperoleh nilai $\geq 70$ hanya sebesar $68.57 \%$ lebih kecil dari persentase ketuntasan yang dikehendaki yaitu sebesar $85 \%$. Hal ini disebabkan karena peserta didik masih belum bisa menyesuaian diri dengan model pembelajaran yang baru tersebut dan guru kurang melatih keterampilan dalam kegiatan pembelajaran.

Dari siklus pertama ini peneliti menemukan beberapa kekurangan :

1. Masih banyak peserta didik yang tidak memperhatikan gurunya menyampaikan materi.

2. Masih ada peserta didik yang malu bertanya pada guru tentang hal yang kurang mengerti sehingga ketuntasan belajar masih rendah, dan masih banyak peserta didik yang tidak bertanggung jawab dalam melaksanakan tugasnya.

\section{Pelaksanaan Siklus Kedua}

Siklus kedua dilaksanakan dalam dua kali pertemuan atau dua kali tatap muka. Siklus ini dilaksanakan pada hari Senin, 26 Agustus 2019 dan hari Senin 2 September 2019 jam ke 3 dan 4 di kelas XI IPA.5 SMA Negeri 1 Ogan Komering Ulu.
Adapun Rekapitulasi Hasil Tes

Formatif Pada Siklus II dapat dilihat pada table di bawah ini:

Tabel 4 Hasil Tes Pada Siklus I

\begin{tabular}{clc}
\hline No. & \multicolumn{1}{c}{ Uraian } & $\begin{array}{c}\text { Siklus } \\
\text { I }\end{array}$ \\
\hline 1 & Nilai rata-rata tes & 72.93 \\
\hline & Jumlah siswa yang tuntas belajar & 32 \\
\hline 3 & $\begin{array}{l}\text { Jumlah siswa yang tidak tuntas } \\
\text { belajar }\end{array}$ & 3 \\
\hline & Persentase ketuntasan belajar & 91.43 \\
\hline & & 8.57 \\
\hline
\end{tabular}

Sedangkan untuk hasil tes pada siklus I dapat dilihat pada tabel berikut:

Tabel 5 Hasil Tes

\begin{tabular}{cc}
\hline Uraian & Siklus I \\
\hline Rata-rata nilai tes pertemuan 1 & 72.00 \\
\hline Rata-rata nilai tes pertemuan 2 & 73.86 \\
\hline Rata-rata nilai & 72.93 \\
\hline
\end{tabular}

Dari tabel di atas dapat dijelaskan bahwa dengan menerapkan pembelajaran dengan menggunakan model pembelajaran Discovery Learning diperoleh nilai rata-rata hasil belajar peserta didik pada pertemuan pertama 72 dan pada pertemuan kedua 73.86, sehingga nilai rata-rata peserta didik pada siklus I ini didapatkan 72.93. Untuk lebih 
jelas dapat dilihat pada grafik di bawah ini:

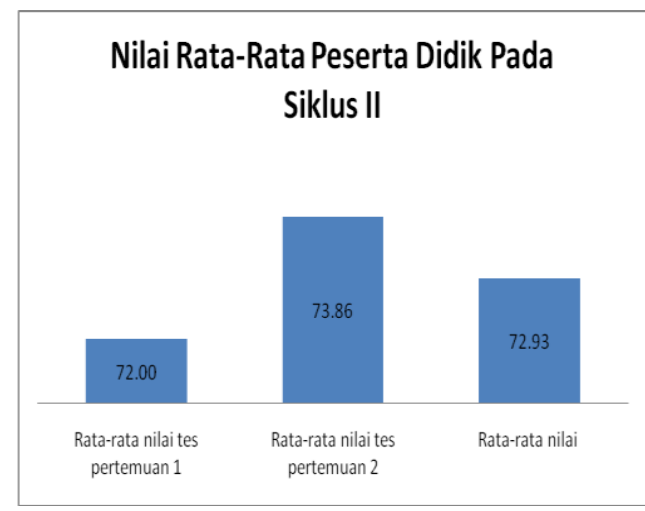

Grafik 2 Nilai Pada Siklus II

Berdasarkan tabel di atas dapat dijelaskan bahwa dengan menerapkan pembelajaran dengan menggunakan model pembelajaran Discovery Learning diperoleh ketuntasan belajar peserta didik pada pertemuan pertama peserta didik yang tuntas belajar hanya 27 orang dan yang tidak tuntas 8 orang. Sedangkan pada pertemuan kedua peserta didik yang tuntas belajar hanya 21, dan yang tidak tuntas 4 orang, jadi dapat disimpulkan rata-rata ketuntasan belajar peserta didik pada siklus II yang tuntas belajar 32 orang dan persentase $91.43 \%$, dan yang belum tuntas 3 arang dengan persentase $8.57 \%$. Maka secara klasikal ketuntasan belajar yang telah tercapai sebesar $91.43 \%$ (termasuk kategori tuntas). Hasil pada siklus II ini mengalami peningkatan lebih baik dari siklus I. Adanya peningkatan hasil belajar pada siklus II ini dipengaruhi oleh adanya peningkatan kemampuan peserta didik dalam mempelajari materi pelajaran yang telah diterapkan selama ini. Hal ini dipengaruhi oleh kemampuan guru dalam mengelola proses belajar mengajar selama kegiatan pembelajaran yang berlangsung.

\section{Pembahasan}

Berdasarkan hasil peneilitian ini menunjukkan bahwa pembelajaran dengan menggunakan model pembelajaran Discovery Learning memiliki dampak positif dalam meningkatkan prestasi belajar peserta didik. Hal ini dapat dilihat dari semakin mantapnya pemahaman dan penguasaan peserta didik terhadap materi yang telah disampaikan guru selama ini ketuntasan belajar meningkat dari sebelum tindakan dan sesudah tindakan, yaitu; pra siklus (31.43\%), siklus I (68.57\%), dan siklus II (91.43\%). Pada siklus II ketuntasan belajar peserta didik secara klasikal telah tercapai dan mengalami peningkatan yang sangat baik. Adapun perkembangan hasil belajar peserta didik dapat dilihat pada tabel berikut ini: 
Tabel 6 Perkembangan Hasil Belajar Peserta didik

\begin{tabular}{|c|c|c|c|}
\hline Siklus & $\begin{array}{l}\text { Persentase } \\
\text { Ketuntasan }\end{array}$ & $\begin{array}{c}\text { Jumlah } \\
\text { Ketuntasan }\end{array}$ & $\begin{array}{l}\text { Nilai } \\
\text { Rata } \\
\text { Rata }\end{array}$ \\
\hline $\begin{array}{c}\text { Pra } \\
\text { Siklus }\end{array}$ & 31.43 & 11 & $\begin{array}{c}62.5 \\
7 \\
\end{array}$ \\
\hline Siklus I & 68.57 & 24 & 70 \\
\hline Siklus II & 91.43 & 32 & $\begin{array}{c}72.9 \\
3\end{array}$ \\
\hline
\end{tabular}

Untuk lebih jelas dapat dilihat pada grafik di bawah ini:

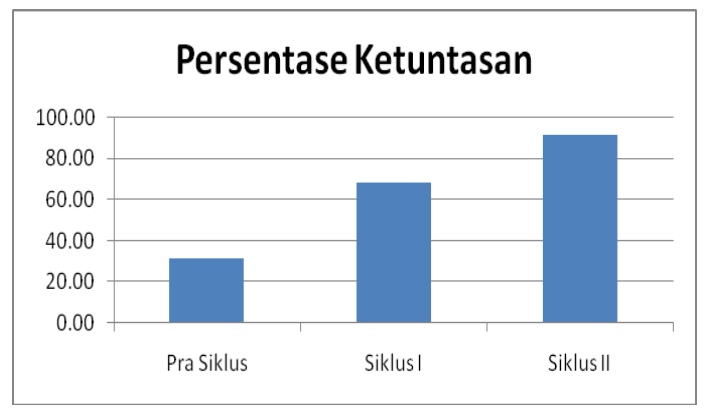

Grafik 3 Hasil belajar peserta didik sebelum tindakan dan sesudah tindakan

\section{KESIMPULAN DAN SARAN}

\section{Kesimpulan}

Berdasarkan hasil penelitian yang telah dikemukakan pada bab sebelumnya, maka kesimpulan yang dapat diambil dalam penelitian ini adalah sebagai berikut: model pembelajaran Discovery Learning memiliki dampak positif dalam meningkatkan hasil belajar peserta didik yang ditandai dengan peningkatan ketuntasan belajar meningkat dari hasil belajar sebelum tindakan dan sesudah tindakan yaitu pra siklus (31.43\%), siklus I $(68.57 \%)$, dan siklus II $(91.43 \%)$. Penerapan model pembelajaran Discovery Learning mempunyai pengaruh positif, yaitu dapat meningkatkan motivasi belajar peserta didik yang ditunjukan dengan hasil observasi yang guru pengamat lihat, dan peserta didik tertarik terhadap penggunaan model pembelajaran Discovery Learning mereka menjadi termotivasi untuk belajar.

\section{Saran}

Untuk melaksanakan pembelajaran memerlukan persiapan yang cukup matang, sehingga guru harus mampu menentukan atau memilih topik yang benar-benar bisa diterapkan dengan pembelajaran PAI dalam proses belajar mengajar sehingga diperoleh hasil yang optimal. Dalam rangka meningkatkan hasil belajar peserta didik, guru hendaknya lebih sering melatih peserta didik dengan berbagai model pembelajaran, walau dalam taraf yang sederhana, dimana peserta didik nantinya dapat menemukan pengetahuan baru, memperoleh konsep dan keterampilan, sehingga peserta didik berhasil atau mampu memecahkan masalah-masalah yang dihadapinya.Perlu adanya penelitian 
yang lebih lanjut, karena hasil penelitian ini hanya dilakukan di SMA Negeri 1 Ogan Komering Ulu.

\section{DAFTAR PUSTAKA}

Arends, Richard I. 2007. Learning to Teach Belajar untuk Mengajar. Yogyakarta: Pustaka Belajar.

Felder, Richard M, 1994. Cooperative Learning in Technical Corse (online)

Kusumah, U. W., 2009. Prosedur Dan Langkah-Langkah Penelitian. Diundu h dari: http: //repository. usu.ac.id/ xmlui/ handle/ 123456789/6456. [Diakses Agustus 2019].

Oemar Hamalik. 2009. Proses Belajar Mengajar. Bandung: Bumi Aksara.

Sagala, S. 2010. Konsep dan Makna Pembelajaran. Bandung : Alfabeta

Setyaningsih. 2001. Pembelajaran Kooperatif. http://ipotes.wordpress.com/2008/ 05/15/pembelajaran-kooperatiftipe-/49 ( 14 Agustus 2019. 15.00 )
2008. Menjadi Guru Profesional.

Bandung: PT Remaja Rosdakarya.

Wahyuni, Sri. 2001. Kinerja Kelompok Tani Dalam Sistem Usahatani Padi dan Metode Pemberdayaannya. Jurnal Litbang Pertanian. Bogor 